\title{
Safety and efficacy of tinea pedis and onychomycosis treatment in people with diabetes: a systematic review
}

\author{
Lisa Matricciani, Kerwin Talbot and Sara Jones
}

\begin{abstract}
Background: Effective treatment of tinea pedis and onychomycosis is crucial for patients with diabetes as these infections may lead to foot ulcers and secondary bacterial infections resulting in eventual lower limb amputation. Although numerous studies have assessed the effectiveness of antifungal drug and treatment regimens, most exclude patients with diabetes and examine otherwise healthy individuals. While these studies are useful, results cannot necessarily be extrapolated to patients with diabetes. The purpose of this study was to therefore identify the best evidence-based treatment interventions for tinea pedis or onychomycosis in people with diabetes.

Methods: The question for this systemic review was: 'what evidence is there for the safety and/or efficacy of all treatment interventions for adults with tinea pedis and/or onychomycosis in people with diabetes'? A systematic literature search of four electronic databases (Scopus, EbscoHost, Ovid, Web of Science) was undertaken (6/1/11). The primary outcome measure for safety was self-reported adverse events likely to be drug-related, while the primary outcome measures assessed for 'efficacy' were mycological, clinical and complete cure.

Results: The systematic review identified six studies that examined the safety and/or efficacy of treatment interventions for onychomycosis in people with diabetes. No studies were identified that examined treatment for tinea pedis. Of the studies identified, two were randomised controlled trials (RCTs) and four were case series. Based on the best available evidence identified, it can be suggested that oral terbinafine is as safe and effective as oral itraconazole therapy for the treatment of onychomycosis in people with diabetes. However, efficacy results were found to be poor.
\end{abstract}

Conclusions: This review indicates that there is good evidence (Level II) to suggest oral terbinafine is as safe and effective as itraconazole therapy for the treatment of onychomycosis in people with diabetes. Further research is needed to establish the evidence for other treatment modalities and treatment for tinea pedis for people with diabetes. Future efforts are needed to improve the efficacy of treatment intervention.

Keywords: Onychomycosis, tinea pedis, diabetes, treatment, safety, efficacy

\section{Introduction}

Diabetes affects approximately 285 million people worldwide, with estimates expected to rise to 438 million in 2030 [1]. Diabetes is associated with a number of serious and costly health complications, in particular, diabetic foot ulcers $[2,3]$. Foot ulcers cause considerable disability [4,5], morbidity [6] and are the leading cause of foot amputations and hospitalisations among people

\footnotetext{
* Correspondence: matla005@mymail.unisa.edu.au

School of Health Sciences, University of South Australia, North Terrace, Adelaide, South Australia, 5000, Australia
}

with diabetes [7-11]. While measures such as foot care and patient education are acknowledged as effective strategies to prevent foot ulcers $[12,13]$, the importance of treating tinea pedis and onychomycosis (fungal infections of the foot and toenails) is becoming increasingly recognised [14,15] with evidence to suggest that tinea pedis and onychomycosis are significant predictors in the development of foot ulcers [16]. This is particularly concerning for people with diabetes, who are 2.5 to 2.8 times more likely to have these conditions (i.e. tinea 
pedis and onychomycosis) than otherwise healthy individuals [17].

Both tinea pedis and onychomycosis may lead to the development of foot ulcers. Onychomycosis may result in foot ulceration as a result of a thick, sharp, brittle piece of nail piercing the skin, or as a result of vascular compromise arising from increased subungal pressure due to enlarged dystrophic nails $[15,18]$. Tinea pedis may also result in the formation of foot ulcers through the development of fissures in the plantar and/or interdigital skin. In both cases, injury creates a portal of entry for pathogens which promotes the development of further complications including cellulitis, osteomyelitis, gangrene and lower limb amputation. While the association between foot ulceration and the presence of tinea pedis and/or onychomycosis has not been formally tested, evidence [19-23] exists to suggest that patients with cellulitis, osteomyelitis and gangrene are also likely to have tinea pedis and/or onychomycosis. Patients with diabetes are at an increased risk of developing these complications as they often present with an impaired ability to detect injury as a result of peripheral neuropathy, retinopathy and also obesity, which may inhibits foot inspection [24,25]; as well as an impaired ability to fight infection due to elevated blood glucose levels and altered immune function [26]. Studies [24,27] also indicate that patients with diabetes and onychomycosis have a significantly higher rate of foot ulceration, gangrene and a combination of foot ulcer and gangrene compared to diabetic patients without onychomycosis. Effective and safe treatment of tinea pedis and onychomycosis is therefore especially important for patients with diabetes as it may prevent ulcer formation and secondary complications [28].

While the importance of effective and safe treatment of tinea pedis and onychomycosis in people with diabetes has been emphasised in the literature, many studies have aimed to determine the efficacy and safety of antifungal treatment interventions in otherwise healthy individuals. While these studies are of importance, results cannot necessarily be extrapolated to patients with diabetes. Firstly, people with diabetes often present with polypharmacy, many of which have the potential to interact with antifungal medication [29]. Secondly, people with diabetes tend to be resistant to treatment as high blood glucose levels and an inability to keep feet clean and dry due to obesity and/or retinopathy fosters fungal growth [30].

Many studies acknowledge the complexity of treating tinea pedis and onychomycosis in people with diabetes and provide recommendations for safe and effective treatment $[14,18,30-36]$. To date, there do not appear to be any studies that provide a comprehensive evidencebased review of the evidence for the safety and efficacy of different treatment interventions for tinea pedis and/ or onychomycosis in people with diabetes. The purpose of this study was therefore, to determine the evidence available for the safety and efficacy of all treatment interventions and modalities for tinea pedis and onychomycosis in patients with diabetes.

\section{Methods}

A systematic literature search was conducted to determine the evidence for all antifungal treatment interventions for adults (aged 18 years and older) with tinea pedis and/or onychomycosis of the toenails in people with diabetes.

\section{Criteria for inclusion}

Any study that examined the safety and/or efficacy of a treatment intervention for tinea pedis and/or onychomycosis of the toenails in adults with Type 1 or Type 2 diabetes was considered for inclusion in this review. Only studies that used microscopy and culture to establish the presence of fungal infections were included. The primary outcome measures assessed in this review were 'safety' and 'efficacy'. 'Safety' was defined as any selfreported adverse events likely to be related to the treatment intervention, while 'efficacy' included measures of mycological cure, defined as negative potassium hydroxide culture; clinical cure, defined as less than $10 \%$ nail involvement and complete cure, which was defined as complete mycological and clinical cure. Studies that did not provide sufficient detail of the diagnosis, treatment regimen or the outcome variables were excluded from this review, as were studies that examined onychomycosis of the hands. Two reviewers (LM and KT) independently applied these criteria to locate trials for this review.

\section{Systematic search strategy}

Four electronic databases (Scopus, EbscoHost, Ovid, Web of Science) were searched using the search strategy summarised in Table 1. A preliminary search determined the scope and relevance of candidate databases. All abstracts were screened for inclusion criteria. Potentially eligible papers were read in full and all relevant papers were kept and included in this review. No date or language limits were set. The last search was carried out was on January 6 2011. Reference lists of all eligible papers were reviewed to locate any additional studies. No date limits were set, however, only papers written in English were considered for inclusion.

\section{Evaluation, analysis and synthesis of studies included for review}

All studies included in this review were read by two reviewers independently (LM and $\mathrm{KT}$ ) for content 
Table 1 Search strategy used for each database.

\begin{tabular}{llll}
\hline Database & Date & Limitation & Search Terms \\
\hline Scopus & $15 / 10 / 10$ & Abstract & ((ABS("Tinea Pedis" OR "onychomycosis" OR "athlete's foot"))) AND ((ABS(diab*)) AND (ABS(treat*)). \\
Ovid & $6 / 1 / 11$ & Abstract & ((Tinea Pedis OR onychomycosis OR athlete's foot) and (treat\$) and (diab\$) \\
Web of Science & $6 / 1 / 11$ & Topic & Topic = ("Tinea Pedis" OR "onychomycosis" OR "athlete's foot") AND Topic = (diab*) AND Topic = (treat*) \\
EbscoHost & $15 / 10 / 10$ & Abstract & AB ("Tinea Pedis" OR "onychomycosis" OR "athlete's foot") and AB (diab*) and AB (treat*) \\
\hline
\end{tabular}

extraction and appraised for their level of evidence using the NHMRC hierarchy of evidence scale [37] (Table 2). Each study was then independently evaluated for its internal and external validity and rated according to the scale [38] provided by the American Occupational Therapy Association's (AOTA) Evidence-Based Practice Project (Table 3). Specific threats to validity were also identified and recorded. All studies were assessed by two independent reviewers (LM and KT) and any discrepancies were resolved by a third independent reviewer (SJ).

The methodological quality of all randomized controlled trials (RCTs) included in this review were further appraised using the PEDro scale. The PEDro scale has established reliability [39] and provides a score out of 11 which provides a measure of the validity of a study's conclusions. Question 1 relates to the external validity, questions 2-9 relates to internal validity and questions 10-11 relates to whether the study contains sufficient statistical information to make the results interpretable. These articles were also assessed by two independent (LM and KT) reviewers and any discrepancies were resolved by a third independent reviewer (SJ).

\section{Results}

The systematic review identified 14 different studies that examined the efficacy and/or safety of treatment interventions for onychomycosis and/or tinea pedis in people with diabetes (Figure 1). Of these, four [19,40-42] were excluded because they did not provide sufficient detail about the diagnosis of infection and/or the outcome variables assessed and two $[43,44]$ were excluded because they assessed treatments interventions for onychomycosis of the toenails and fingernails and did provide results for the two separate conditions. A further

\section{Table 2 NHMRC Hierarchy of evidence}

\begin{tabular}{ll}
\hline $\begin{array}{l}\text { Level of } \\
\text { evidence }\end{array}$ & Study design \\
\hline$I^{*}$ & A systematic review of level II studies \\
$\|$ & A randomised controlled trial \\
|| $\mid-1$ & A pseudorandomised controlled trial \\
$|I|-2$ & A comparative study with concurrent controls \\
|| $\mid-3$ & A comparative study without concurrent controls \\
IV & Case series with either post-test or pre-test/post-test \\
& outcomes
\end{tabular}

two $[45,46]$ studies could not be included because an abstract or full text copy of the study could not be located, despite efforts to contact the authors and searching overseas libraries. Thus, a total of six different studies [47-52] were in included in this review.

Of the six [47-52] studies included in this review, two [50,51] examined safety, one [47] examined efficacy and three $[48,49,52]$ examined both the safety and efficacy of a treatment intervention (Table 4). All studies examined treatment for onychomycosis. None examined treatment for tinea pedis. While we searched for both pharmacological and non-pharmacological antifungal treatment interventions, only pharmacological interventions were assessed in trials that determined efficacy. The same interventions were also examined in trials that assessed safety, one [51] study also examined palliative treatment, which consisted of toenail trimming and cleaning. The pharmacological interventions examined included continuous oral terbinafine therapy, pulse oral itraconazole therapy and daily topical ciclopirox $8 \%$ therapy with mechanical debridement every eight weeks. There were no trials examining alternative medical therapies.

As shown in Table 5, two $[48,51]$ studies provided level II evidence [randomised controlled trials (RCT)] and four $[47,49,50,52]$ studies provided level IV evidence (case series). Internal validity varied across studies. Of the six studies, one [48] scored 'high', three [47,50,52] scored 'moderate' and two $[49,51]$ scored 'low' for internal validity. Common threats to internal validity included a lack of blinding and attrition. External validity scores also varied across studies, but to a lesser extent. In total, two studies were found to have high external validity and four studies were found to have moderate external validity. Common threats to external validity included the inclusion of participants who were not truly representative of people with diabetes. All studies were limited by a small sample size.

Table 6 presents the PEDro scores for the two RCTs included in this review. As shown, Albreski and colleagues [51], scored much lower than Gupta and colleagues [48] due to blinding and participant allocations.

\section{Safety of antifungal treatment interventions in diabetic patients \\ A total of five [48-52] different studies examined the safety of treatment interventions for onychomycosis in}




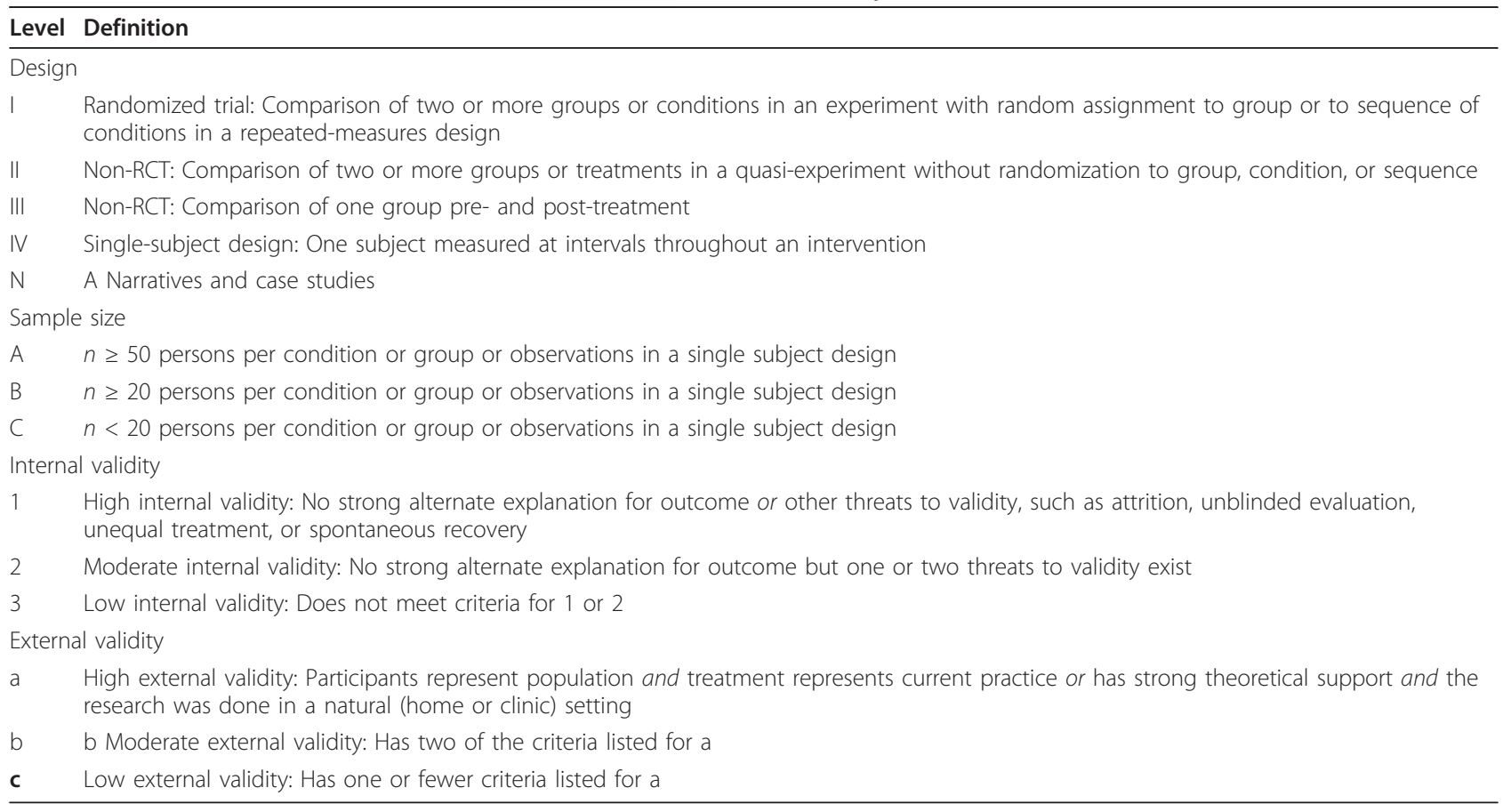

AOTA-American Occupational Therapy association; RCT-Randomised controlled trial. Figure taken from Tromblay and Ma [38]

people with diabetes. Of these, two $[48,51]$, were randomised controlled trials and three $[49,50,52]$ were case series. Internal validity was considered 'high' for only one [48] study, while external validity was considered 'high' for two $[48,52]$ studies.

Table 7 presents the results of the five studies that examined the safety of treatment interventions. As shown, all studies reported few or no adverse events that were likely to have been related to the treatment. None of the studies reported any life threatening adverse events that were likely to be due to treatment. The most common reported adverse event was gastrointestinal pain, which was reported for both terbinafine and itraconazole therapy. The safest interventions were palliative care and oral terbinafine therapy, which, according to Albreski and colleagues [51] and Gupta and colleagues [48] (respectively), did not produce any adverse events. The greatest number of adverse events were reported in the study by Brenner and colleagues [49], who investigated the safety of topical ciclopirox $8 \%$ with mechanical nail debridement every eight weeks. In this study, adverse events likely to be due to treatment occurred in $29 \%(14 / 49)$ of participants.

Gupta and colleagues [48] provided the highest level of evidence for the safety of antifungal treatment interventions for onychomycosis in people with diabetes. In this study, there was no significant difference in the safety of oral terbinafine (0\%) and itraconazole (8.6\%). Thus, the best available evidence indicates continuous oral terbinafine is as safe as pulse oral itraconazole therapy for treating onychomycosis in people with diabetes.

\section{Efficacy of antifungal treatment interventions in diabetic patients}

A total of four [47-49,52] different studies examined the efficacy of treatment interventions for onychomycosis in people with diabetes. Of these, one [48] was a RCT and three $[47,49,52]$ were case series. Internal and external validity was found to be moderate to high in all but one [49] study.

As shown in Figure 2 and Table 8 at week 48, mycological and complete cure was highest for oral itraconazole therapy, followed by oral terbinafine and topical ciclopirox $8 \%$ therapy. In contrast, clinical cure was slightly greater for oral terbinafine therapy than for oral itraconazole therapy. However, as shown, this was not consistent across studies. While there was slight differences amongst studies, Gupta and colleagues [48] provided the strongest evidence. In this study, there was no significant difference in the effectiveness of itraconazole and terbinafine in achieving mycological, clinical and complete cure. It can therefore be inferred that current, best available evidence suggests that pulse oral itraconazole therapy is as effective as continuous oral terbinafine therapy at achieving mycological, clinical and complete cure of onychomycosis in people with diabetes.

While Brenner and colleagues [49] found daily, topical application of ciclopirox $8 \%$ to result in poor efficacy 


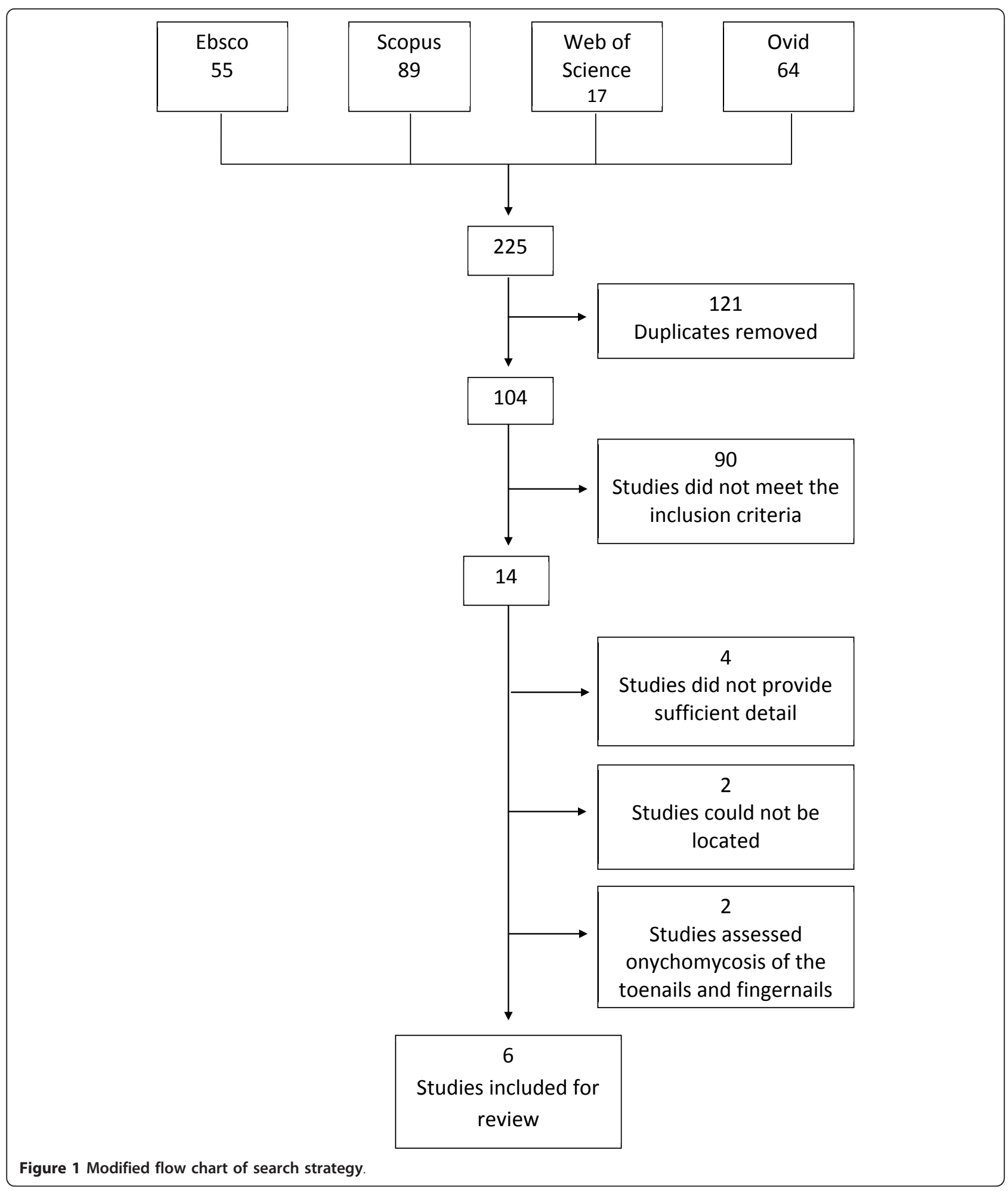


Table 4 Summary of studies included for review

\begin{tabular}{|c|c|c|c|c|c|c|c|}
\hline $\begin{array}{l}\text { Study } \\
\text { [ref] }\end{array}$ & Design & $\begin{array}{l}\text { Subjects } \\
\mathrm{n} \\
\text { (males) }\end{array}$ & $\begin{array}{l}\text { Age } \\
\text { Mean } \\
\text { (SD) }\end{array}$ & Intervention & $\begin{array}{l}\text { Assessment } \\
\text { (weeks) }\end{array}$ & $\begin{array}{l}\text { Outcome measures } \\
\text { Safety }\end{array}$ & $\begin{array}{l}\text { Outcome measures } \\
\text { Efficacy }\end{array}$ \\
\hline \multirow[t]{2}{*}{$\begin{array}{l}\text { Pollak } \\
\text { [44] }\end{array}$} & $\begin{array}{l}\text { Case } \\
\text { series }\end{array}$ & 77 (N/R) & $N / R$ & $\begin{array}{l}\text { Active Intervention: } 250 \\
\text { mg oral terbinafine once } \\
\text { daily for } 12 \text { weeks }\end{array}$ & $\begin{array}{l}0,6,12,18, \\
24,30,36 \\
48,72\end{array}$ & $\begin{array}{l}\text { Participant and investigator- } \\
\text { reported adverse events. } \\
\text { Severity (mild, moderate, } \\
\text { severe, life-threatening) and } \\
\text { likelihood of adverse event } \\
\text { related to treatment (yes, no, } \\
\text { uncertain) determined by } \\
\text { investigator }\end{array}$ & Not assessed \\
\hline & & & & Control : no control & & & \\
\hline \multirow[t]{2}{*}{$\begin{array}{l}\text { Albreski } \\
\text { [45] }\end{array}$} & $\mathrm{RCT}$ & $52(51)$ & $\begin{array}{l}71.42 \\
(6.21) \\
\text { years }\end{array}$ & $\begin{array}{l}\text { Active Intervention: } 200 \\
\text { mg of oral itraconazole } \\
\text { twice daily for one week } \\
\text { over three consecutive } \\
\text { months }\end{array}$ & $0,2,10,32$ & $\begin{array}{l}\text { Investigator-reported adverse } \\
\text { events and likelihood that } \\
\text { any adverse events were } \\
\text { related to drug therapy }\end{array}$ & Not assessed \\
\hline & & & & $\begin{array}{l}\text { Control: Toenail trimming, } \\
\text { cleaning and soaking for } 4 \\
\text { months. }\end{array}$ & & & \\
\hline \multirow[t]{2}{*}{$\begin{array}{l}\text { Brenner } \\
\text { [43] }\end{array}$} & $\begin{array}{l}\text { Case } \\
\text { series }\end{array}$ & $49(36)$ & $\begin{array}{l}63.8 \\
(12.0) \\
\text { years }\end{array}$ & $\begin{array}{l}\text { Active Intervention: Daily } \\
\text { topical application of } \\
\text { Ciclopirox } 8 \% \text { nail lacquer } \\
\text { with mechanical } \\
\text { debridement every eight } \\
\text { weeks for } 48 \text { weeks. }\end{array}$ & $\begin{array}{l}0,8,16,24 \\
32,40,48\end{array}$ & $\begin{array}{l}\text { Participant and investigator- } \\
\text { reported adverse events. } \\
\text { Severity and likelihood of } \\
\text { adverse event related to } \\
\text { treatment determined by } \\
\text { investigator. }\end{array}$ & $\begin{array}{l}\text { Mycological cure: negative } \\
\text { results on microscopy (KOH) } \\
\text { and fungal culture. Clinical } \\
\text { cure: } \geq 90 \% \text { improvement } \\
\text { (from baseline) in diseased } \\
\text { nail. Complete cure: } \\
\text { mycological cure plus clinical } \\
\text { cure. }\end{array}$ \\
\hline & & & & Control: no control & & & \\
\hline \multirow[t]{2}{*}{$\begin{array}{l}\text { Farkas } \\
{[46]}\end{array}$} & $\begin{array}{l}\text { Case } \\
\text { series }\end{array}$ & $89(47)$ & $\begin{array}{l}55.7 \\
(11.7) \\
\text { years }\end{array}$ & $\begin{array}{l}\text { Active intervention: } 250 \\
\mathrm{mg} \text { oral terbinafine once } \\
\text { daily for } 12 \text { weeks. }\end{array}$ & $\begin{array}{l}0,4,8,12 \\
24,36,48\end{array}$ & $\begin{array}{l}\text { Self-reported adverse event } \\
\text { (severity was scored as mild, } \\
\text { moderate or severe) and the } \\
\text { likelihood of any adverse } \\
\text { events being related to the } \\
\text { intervention (non, unlikely, } \\
\text { possible, probably, certain) }\end{array}$ & $\begin{array}{l}\text { Mycological cure: negative } \\
\text { results on microscopy and } \\
\text { fungal culture of samples } \\
\text { taken from the target toe nail. } \\
\text { Clinical cure: } 100 \% \text { clearing of } \\
\text { the target toenail. Complete } \\
\text { cure: mycological cure plus } \\
\text { clinical cure }\end{array}$ \\
\hline & & & & Control: no control & & & \\
\hline \multirow[t]{2}{*}{$\begin{array}{l}\text { Gupta } \\
{[42]}\end{array}$} & $\mathrm{RCT}$ & $70(34)$ & $\begin{array}{l}60.67 \\
(1.52) \\
\text { years }\end{array}$ & $\begin{array}{l}\text { Active intervention: } 200 \\
\text { mg oral itraconazole twice } \\
\text { daily for one week of three } \\
\text { consecutive months }\end{array}$ & $\begin{array}{l}0,1,6,12,24 \\
36,48,60,72\end{array}$ & $\begin{array}{l}\text { Self-reported adverse event } \\
\text { and the likelihood of any } \\
\text { adverse events being related } \\
\text { to the intervention }\end{array}$ & $\begin{array}{l}\text { Mycological cure: negative } \\
\text { results on microscopy and } \\
\text { fungal culture. Clinical cure: } \leq \\
10 \% \text { nail plate involvement. } \\
\text { Effective cure: mycological cure } \\
\text { plus either clinical cure. }\end{array}$ \\
\hline & & & & $\begin{array}{l}\text { Control: } 250 \mathrm{mg} \text { oral } \\
\text { terbinafine daily for } 12 \\
\text { weeks. }\end{array}$ & & & \\
\hline \multirow[t]{2}{*}{$\begin{array}{l}\text { Sadighha } \\
\text { [41] }\end{array}$} & $\begin{array}{l}\text { Case } \\
\text { series }\end{array}$ & $13(\mathrm{~N} / \mathrm{R})$ & $\begin{array}{l}50-73 \\
\text { years }\end{array}$ & $\begin{array}{l}\text { Active intervention: } 200 \\
\mathrm{mg} \text { oral itraconazole twice } \\
\text { daily for one week of four } \\
\text { consecutive months }\end{array}$ & 0,26 & Not assessed & $\begin{array}{l}\text { Complete cure: negative } \\
\text { mycological culture and } \\
\text { resolution of nail deformity. }\end{array}$ \\
\hline & & & & Control: no control & & & \\
\hline
\end{tabular}

$\mathrm{RCT}=$ Randomised controlled trial

$\mathrm{N} / \mathrm{R}=$ not reported

all studies, except that by Farkas and colleagues [46] assessed people with Type 2 diabetes. Farkas and colleagues did not find any significant differences in the treatment outcomes for patients with Type 1 and Type 2 diabetes, the pooled results from this study were considered in this review

outcomes, the internal validity for this study was low and the external validity was moderate. Current available evidence is therefore unable to provide a confident indication of the efficacy of ciclopirox $8 \%$ for the treatment of onychomycosis in adults with diabetes.

\section{Discussion}

\section{Main findings}

This systematic literature review identified six different studies that examined the safety and/or efficacy of antifungal treatment interventions for onychomycosis of the 
Table 5 Appraisal of the validity of the studies included for review using the AOTA scale

\begin{tabular}{|c|c|c|c|c|c|c|}
\hline Study & $\begin{array}{l}\text { Level of } \\
\text { Evidence }^{+}\end{array}$ & $\begin{array}{l}\text { Sample } \\
\text { size }\end{array}$ & $\begin{array}{l}\text { Internal } \\
\text { validity }\end{array}$ & $\begin{array}{l}\text { Possible threats to internal } \\
\text { validity }\end{array}$ & $\begin{array}{l}\text { External } \\
\text { validity }\end{array}$ & Possible threats to external validity \\
\hline $\begin{array}{l}\text { Pollak } \\
{[44]}\end{array}$ & IV & A & $\begin{array}{l}\text { 2- } \\
\text { Moderate }\end{array}$ & Unblinded & B-Moderate & $\begin{array}{l}\text { Treatment may not represents current practice: } \\
\text { - Participants had to have toenails that the } \\
\text { investigators believed were capable of regrowth } \\
\text { - Onychomycosis must have been dermatophyte- } \\
\text { caused } \\
\text { - Patients may not be representative of the diabetic } \\
\text { population: } \\
\text { - Patients were not allowed to participants if they had } \\
\text { abnormal laboratory results } \\
\text { - Detail of diabetic population not provided (age, sex } \\
\text { ratio, coexisting medical conditions, use of other } \\
\text { medications etc. }\end{array}$ \\
\hline $\begin{array}{l}\text { Albreski } \\
{[45]}\end{array}$ & $\|$ & B & 3-Low & $\begin{array}{l}\text { Unblinded } \\
\text { Duration of diabetes different } \\
\text { between groups } \\
\text { More people in the itraconazole } \\
\text { group received insulin } \\
\text { compared with palliative group }\end{array}$ & B-Moderate & $\begin{array}{l}\text { Patients may not be representative of the diabetic } \\
\text { population: } \\
\text { - Participants were excluded if they were taking certain } \\
\text { medication, such as medication for high cholesterol, } \\
\text { which patients with diabetes are likely to be on } \\
\text { - Only one female assessed }\end{array}$ \\
\hline $\begin{array}{l}\text { Brenner } \\
{[43]}\end{array}$ & IV & B & 3-Low & $\begin{array}{l}\text { Unblinded } \\
\text { Attrition } \\
\text { Patients were allowed to use } \\
\text { other antifungal agents for } \\
\text { coexisting tinea pedis } \\
\text { Patients received also received } \\
\text { nail care treatment }\end{array}$ & B-Moderate & $\begin{array}{l}\text { Patients may not be representative of the diabetic } \\
\text { population: } \\
\text { - Patients had to have a good history of scheduled } \\
\text { podiatric medical visits for nail care, be in good } \\
\text { general health have good pulses. }\end{array}$ \\
\hline $\begin{array}{l}\text { Farkas } \\
{[46]}\end{array}$ & IV & A & $\begin{array}{l}\text { 2- } \\
\text { Moderate }\end{array}$ & $\begin{array}{l}\text { Unblinded } \\
\text { Attrition }\end{array}$ & A-High & nil \\
\hline $\begin{array}{l}\text { Gupta } \\
{[42]}\end{array}$ & $\|$ & B & 1-High & nil & A-High & nil \\
\hline $\begin{array}{l}\text { Sadighha } \\
\text { [41] }\end{array}$ & IV & C & $\begin{array}{l}\text { 2- } \\
\text { Moderate }\end{array}$ & $\begin{array}{l}\text { Unblinded } \\
\text { Selection criteria not clearly } \\
\text { stated }\end{array}$ & B-Moderate & $\begin{array}{l}\text { Patients may not be representative of the diabetic } \\
\text { population: } \\
\text { - Detail of diabetic population not provided (age, sex } \\
\text { ratio, coexisting medical conditions, use of other } \\
\text { medications etc.) }\end{array}$ \\
\hline
\end{tabular}

${ }^{\dagger}$ For consistency, the NHMRC study design classification system was used instead of the AOTA study design classification system

toenails in adults with diabetes. Of these, two [48,51] were RCTs and four $[47,49,50,52]$ were case series. Not a single study examined treatment interventions for tinea pedis. From the available studies, the strongest evidence suggests that continuous oral terbinafine therapy is as safe and effective as pulse itraconazole therapy for treating onychomycosis.

\section{Strengths and limitations}

This is the first systematic literature review to examine the evidence for the safety and/or efficacy of treatment interventions for tinea pedis and onychomycosis of the toenails in adults with diabetes. There are however, several limitations that need to be addressed. Firstly, only studies written in English were included in this review. Secondly, since none of the studies were longitudinal, the safety and efficacy of repeated or long term use of such medications is unclear. Lastly, although this study applied strict inclusion/exclusion criteria for selecting studies to be included in this review, none of the studies explicitly stated how nail involvement was measured and calculated, limiting the reliability of comparisons made between studies that reported clinical cure.

\section{Safety}

The safety of oral antifungal agents for people with diabetes, especially those taking insulin or oral hypoglycaemic medications has raised much interest. Itraconazole and other drugs in the imidazole family (i.e. ketoconazole, fluconazole), act as a competitive inhibitor of the cytochrome P450 (CYP) 3A4 isoenzyme and therefore have the potential to increase the risk of hypoglycemia in people with diabetes who are taking oral hypoglycaemic medication that are metabolised by this pathway [40,53]. Since many other medications are also metabolised by this pathway, itraconazole also has the potential to interact with a myriad of other medications, including HMG-CoA reductase inhibitors, calcium channel blockers, warfarin, cyclosporine, benzodiazepines and certain antiarrythmic medication. Given the nature of diabetes, it is likely that some patients would also be taking some of these medications. 
Table 6 PEDro scores for the RCTs included in this study

\begin{tabular}{|c|c|c|c|c|c|c|c|c|c|c|c|c|}
\hline & $\begin{array}{l}\text { Eligibility } \\
\text { criteria } \\
\text { specified }\end{array}$ & $\begin{array}{l}\text { Random } \\
\text { allocation }\end{array}$ & $\begin{array}{l}\text { Concealed } \\
\text { allocation }\end{array}$ & $\begin{array}{l}\text { Baseline } \\
\text { comparability }\end{array}$ & $\begin{array}{l}\text { Blind } \\
\text { subjects }\end{array}$ & $\begin{array}{l}\text { Blind } \\
\text { therapists }\end{array}$ & $\begin{array}{l}\text { Blind } \\
\text { assessors }\end{array}$ & $\begin{array}{l}\text { Adequate } \\
\text { follow-up }\end{array}$ & $\begin{array}{l}\text { Intention to } \\
\text { treat analysis }\end{array}$ & $\begin{array}{l}\text { Between group } \\
\text { comparisons }\end{array}$ & $\begin{array}{l}\text { Point estimates } \\
\text { and variability }\end{array}$ & $\begin{array}{l}\text { PEDro } \\
\text { Score (/11) }\end{array}$ \\
\hline $\begin{array}{l}\text { Albreski } \\
\text { [45] }\end{array}$ & $Y$ & $Y$ & $\mathrm{~N}$ & $\mathrm{~N}$ & $\mathrm{~N}$ & $\mathrm{~N}$ & $\mathrm{~N}$ & $Y$ & $Y$ & $Y$ & $\mathrm{~N}$ & 5 \\
\hline $\begin{array}{l}\text { Gupta } \\
{[42]}\end{array}$ & $Y$ & $Y$ & $Y$ & $Y$ & $\mathrm{~N}$ & $Y$ & $Y$ & Y & $Y$ & $Y$ & $\mathrm{~N}$ & 9 \\
\hline
\end{tabular}


Table 7 safety outcome results identified in studies included for review

\begin{tabular}{|c|c|c|c|c|c|c|c|c|c|}
\hline Study & Design & Treatment & Treatment regimen & $\begin{array}{l}\text { Sample } \\
\text { size } \\
\text { (males) }\end{array}$ & $\begin{array}{l}\text { Age } \\
\text { [mean } \\
(S D)] \\
\text { years }\end{array}$ & $\begin{array}{l}\text { Safety } \\
\text { assessment } \\
\text { (week) }\end{array}$ & $\begin{array}{l}\text { \% of } \\
\text { patients } \\
\text { experienced } \\
\text { to adverse } \\
\text { events }\end{array}$ & $\begin{array}{l}\% \text { of patients } \\
\text { experienced to } \\
\text { adverse events } \\
\text { due to treatment } \\
\text { intervention }\end{array}$ & $\begin{array}{l}\text { Reported } \\
\text { adverse events } \\
\text { likely to be } \\
\text { related to } \\
\text { treatment } \\
\text { intervention }\end{array}$ \\
\hline $\begin{array}{l}\text { Pollak } \\
{[44]}\end{array}$ & $\begin{array}{l}\text { Case } \\
\text { series }\end{array}$ & Terbinafine & $\begin{array}{l}250 \mathrm{mg} \text { oral terbinafine } \\
\text { once daily for } 12 \text { weekst }\end{array}$ & 77 (N/R) & $N / R$ & $\begin{array}{l}6,12,18,24 \\
30,36,48 \\
72\end{array}$ & $61 \%(47 / 77)$ & $10.4 \%(8 / 77)$ & Gastrointestinal \\
\hline $\begin{array}{l}\text { Albreski } \\
{[45]}\end{array}$ & $\mathrm{RCT}$ & $\begin{array}{l}\text { Itraconazole } \\
\text { Palliative }\end{array}$ & $\begin{array}{l}200 \text { mg of oral } \\
\text { itraconazole taken twice a } \\
\text { day for the first week of } \\
\text { three consecutive months } \\
\text { Toenail trimming, } \\
\text { cleaning and soaking }\end{array}$ & $\begin{array}{l}27(26) \\
25(25)\end{array}$ & $\begin{array}{l}70.52 \\
(7.99) \\
72.32 \\
(4.42)\end{array}$ & $\begin{array}{l}32 \\
32\end{array}$ & $\begin{array}{l}15 \%(4 / 27) \\
0 \%\end{array}$ & $\begin{array}{l}4 \%(1 / 27) \\
0 \%\end{array}$ & $\begin{array}{l}\text { Elevated liver } \\
\text { function test } \\
\text { N/A }\end{array}$ \\
\hline $\begin{array}{l}\text { Brenner } \\
{[43]}\end{array}$ & $\begin{array}{l}\text { Case } \\
\text { series }\end{array}$ & $\begin{array}{l}\text { Ciclopirox } \\
8 \%\end{array}$ & $\begin{array}{l}\text { Ciclopirox } 8 \% \text { nail lacquer } \\
\text { applied daily to nail and } \\
5 \mathrm{~mm} \text { surrounding skin } \\
\text { for } 48 \text { weeks. Nails care } \\
\text { every } 8 \text { weeks. }\end{array}$ & $49(36)$ & $\begin{array}{l}63.8 \\
(12.0)\end{array}$ & 48 & $44.9 \%(22 / 49)$ & $29 \%(14 / 49)$ & $\begin{array}{l}\text { Toenail disorders } \\
\text { and infection }\end{array}$ \\
\hline $\begin{array}{l}\text { Farkas } \\
{[46]}\end{array}$ & $\begin{array}{l}\text { Case } \\
\text { series }\end{array}$ & Terbinafine & $\begin{array}{l}250 \mathrm{mg} \text { oral terbinafine } \\
\text { once daily for } 12 \text { weeks. }\end{array}$ & $89(47)$ & $\begin{array}{l}55.7 \\
(11.7)\end{array}$ & 36 & $13.5 \%(12 / 89)$ & $7.9 \%(7 / 89)$ & $\begin{array}{l}\text { Gastrointestinal } \\
\text { disturbance, } \\
\text { headache, } \\
\text { change in taste } \\
\text { sensation and }\end{array}$ \\
\hline $\begin{array}{l}\text { Gupta } \\
{[42]}\end{array}$ & $\mathrm{RCT}$ & $\begin{array}{l}\text { Itraconazole } \\
\text { Terbinafine }\end{array}$ & $\begin{array}{l}200 \text { mg of oral } \\
\text { itraconazole taken twice a } \\
\text { day for the first week of } \\
\text { three consecutive months } \\
250 \text { mg oral terbinafine } \\
\text { once daily for } 12 \text { weeks. }\end{array}$ & $\begin{array}{l}35(16) \\
35(18)\end{array}$ & $\begin{array}{l}57.77 \\
(2.3) \\
63.65 \\
(1.9)\end{array}$ & $\begin{array}{l}48 \\
48\end{array}$ & $\begin{array}{l}\text { Not reported } \\
\text { Not reported }\end{array}$ & $\begin{array}{l}8.6 \%(3 / 35) \\
0 \%\end{array}$ & $\begin{array}{l}\text { Gastrointestinal } \\
\text { N/A }\end{array}$ \\
\hline
\end{tabular}

RCT-Randomised controlled trial

N/R-Not reported

N/A-Not applicable

${ }^{\dagger}$ According to Health Care Financing Administration [54] guidelines for 4 months.

$\%$ of participants cured

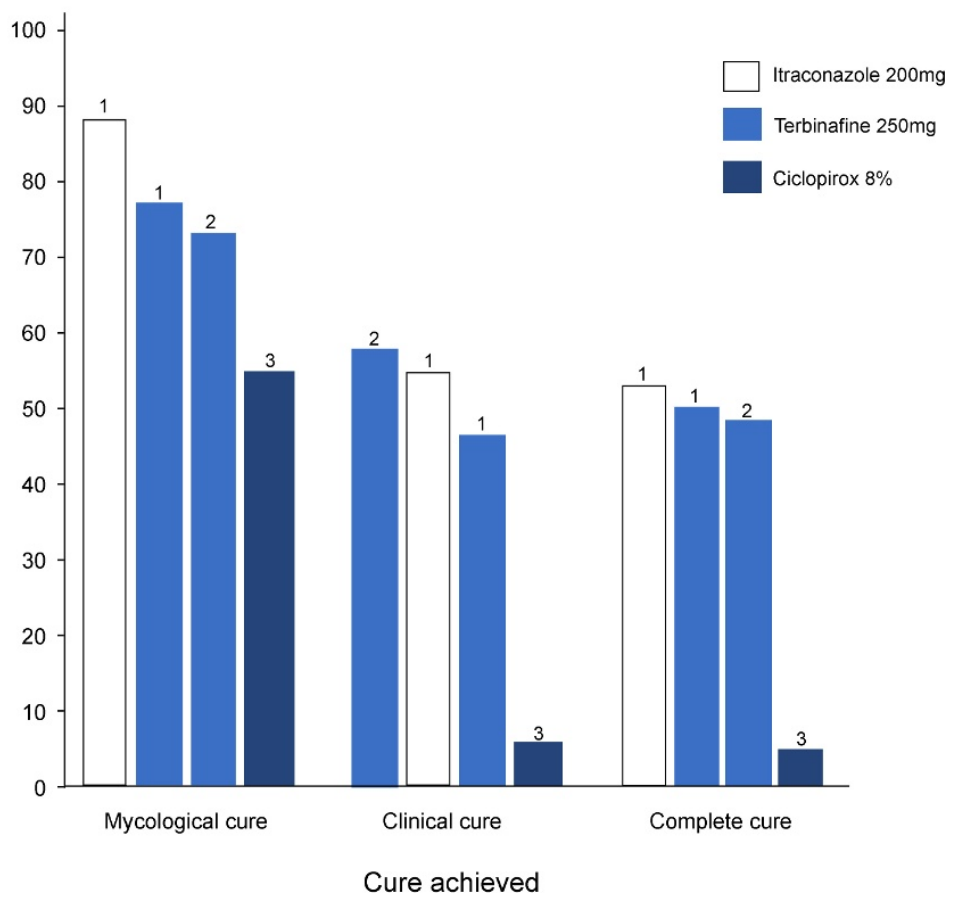

Figure 2 Studies that determined the efficacy of treatment interventions. 
Table 8 Summary of studies that examined the safety of treatment interventions for people with diabetes

\begin{tabular}{|c|c|c|c|c|c|c|}
\hline Study & Design & Subjects & Infection & Organism & Intervention & $\begin{array}{l}\text { Assessment } \\
\text { (week) }\end{array}$ \\
\hline $\begin{array}{l}\text { Gupta } \\
{[42]}\end{array}$ & RCT & $\begin{array}{l}\text { Itraconazole } \\
\mathrm{N}=35 \\
\mathrm{Sex}=16 \mathrm{M} ; 19 \\
\mathrm{~F} \\
\text { Age }=57.77 \\
(2.3) \mathrm{yr} \\
\text { Terbinafine } \\
\mathrm{N}=35 \\
\text { Sex }=18 \mathrm{M} ; 17 \\
\mathrm{~F} \\
\text { Age }=63.65 \\
\text { (1.9) yr }\end{array}$ & DLSO & Dermatophyte & $\begin{array}{l}\text { Ciclopirox } 8 \% \\
\text { Ciclopirox } 8 \% \text { nail lacquer applied to nail and } 5 \mathrm{~mm} \\
\text { surrounding skin. Daily application over the previous coat, } \\
\text { removed after } 7 \text { days using isopropyl alcohol. Nails trimmed } \\
\text { and debrided at each scheduled visit (8 weeks) }\end{array}$ & 48 \\
\hline $\begin{array}{l}\text { Brenner } \\
{[43]}\end{array}$ & $\begin{array}{l}\text { Case } \\
\text { series }\end{array}$ & $\begin{array}{l}\mathrm{N}=49^{\dagger} \\
\text { Sex }=36 \mathrm{M} ; 13 \\
\mathrm{~F} \\
\text { Age }=63.8 \\
\text { (12.0) yr } \\
\text { Duration of } \\
\text { diabetes = } 8.4 \\
\text { (7.4) yr } \\
\text { Duration of } \\
\text { infection = } \\
10.8(15.3) \mathrm{yr}\end{array}$ & $\mathrm{DSO}^{+\dagger}$ & Not reported $^{+}$ & $\begin{array}{l}\text { Terbinafine } \\
250 \mathrm{mg} \text { terbinafine daily } 12 \text { weeks }\end{array}$ & 48 \\
\hline $\begin{array}{l}\text { Farkas } \\
{[46]}\end{array}$ & $\begin{array}{l}\text { Case } \\
\text { series }\end{array}$ & $\begin{array}{l}N=89 \\
\text { Sex }=47 \mathrm{M} ; 42 \\
\mathrm{~F} \\
\text { Age }=55.7 \\
(11.7) \mathrm{yr} \\
\text { Duration of } \\
\text { diabetes = } \\
10.2(7.7) \\
\text { Duration of } \\
\text { infection = } 5.4 \\
(6.0)\end{array}$ & DSO & $\begin{array}{l}\text { Dermatophyte } \\
(67.4 \%) \text {; moulds } \\
(5.6 \%) \text {; yeast }(4.5 \%)\end{array}$ & $\begin{array}{l}\text { Itraconazole pulse therapy } 200 \mathrm{mg} \text { of oral itraconazole taken } \\
\text { twice a day for the first week of three consecutive months } \\
\text { Terbinafine } 250 \mathrm{mg} \text { of oral terbinafine once daily for } 12 \\
\text { weeks. }\end{array}$ & 48 \\
\hline $\begin{array}{l}\text { Sadighha } \\
\text { [41] }\end{array}$ & $\begin{array}{l}\text { Case } \\
\text { series }\end{array}$ & $\begin{array}{l}N=13 \\
\text { Sex }=N R \\
\text { Age }=N R\end{array}$ & $\mathrm{DSO}^{+\dagger}$ & Dermatophyte $^{\dagger}$ & $\begin{array}{l}\text { Pulse itraconazole therapy } 200 \mathrm{mg} \text { of oral itraconazole taken } \\
\text { twice a day for the first week of four consecutive months }\end{array}$ & 26 \\
\hline
\end{tabular}

${ }^{\dagger}$ Concomitant tinea pedis was present.

"DSO" = distal subungual onychomycosis; "DLSO" = distal lateral subungual onychomycosis

Study 4 is excluded from the graph because efficacy was not assessed at week 48 like the rest of the studies. Sadighha [41] found itraconazole achieved cure in $7.7 \%(1 / 13)$ of patients with diabetes at week 26

While the studies included in this review suggests itraconazole "to be safe for patients with diabetes", most studies had limited external validity. Although two [48,52] studies scored 'high' for external validity, these studies examined participants who were taking oral hypoglycaemic medications that are not metabolised by the cytochrome P450 (CYP) 3A4 pathway [48]. Thus, careful consideration is still required before prescribing itraconazole for patients with diabetes.

Unlike, itraconazole, terbinafine is metabolised by the cytochrome P450 (CYP) 2D6 isoenzyme [31]. Since this enzyme is not involved in the metabolism of oral hypoglycaemic medications, terbinafine is unlikely to increase the risk of hypoglycemia in people with diabetes who are taking oral hypoglycaemic medication [48]. Terbinafine may therefore be a safe alternative for people who are unable to take itraconazole.

\section{Efficacy}

Given the complications that may arise if tinea pedis and onychomycosis are not treated, the effectiveness of antifungal treatment interventions is of great importance. While it is often suggested that patients with diabetes are more resistant to antifungal treatment interventions than non-diabetic patients [30], the studies identified in this review presented cure rates that were comparable to people who did not have diabetes. In spite of this, the overall complete cure rate was between $7.7 \%$ and $52.9 \%$ after 48 weeks of treatment, this is a considerable length of time for a patient to be at an increased risk of developing a foot ulcer. It is also a significant number of patients who are never cured during this period of time, but who still have the expense of treatment and who have possibly incurred the unwanted side effects of the medications. A treatment intervention 
that achieves a greater cure rate and provides cure in a shorter time period is therefore needed for patients with diabetes.

\section{Conclusion}

This review indicates that there is good evidence (Level II) to suggest that continuous oral terbinafine is as safe and effective as pulse oral itraconazole therapy for the treatment of onychomycosis in people with diabetes. However, efficacy results are poor. There is no evidence for the treatment of tinea pedis for people with diabetes. While there are numerous alternative and adjunctive antifungal treatment interventions, including mechanical debridement, combination therapy and podiatric intervention that have been recommended for patients with diabetes within the literature, such alternative options have never been examined. Based on the paucity of studies identified and the overall poor efficacy of examined antifungal agents, further research is needed to determine the evidence for alternative treatment modalities and to identify interventions that provide safe and more effective treatment of tinea pedis and onychomycosis in people with diabetes.

\section{Acknowledgements}

Associate Professor Marie Williams and Professor Tim Olds for suggestions regarding the structure of the manuscript and general advice.

\section{Authors' contributions}

LM carried out the systematic review and study appraisal and drafted the manuscript. KT carried out the systematic review and study appraisal. SJ assisted to locate studies of relevance for the study and assisted in the appraisal of included studies. All authors read and approved the final manuscript.

\section{Competing interests}

The authors declare that they have no competing interests. This study received no funding

Received: 12 October 2011 Accepted: 4 December 2011

Published: 4 December 2011

\section{References}

1. Diabetes facts. [http://worlddiabetesfoundation.org/composite-35.htm].

2. Williams R, Van Gaal L, Lucioni C: Assessing the impact of complications on the costs of Type II diabetes. Diabetologia 2002, 45.

3. Boulton A, Vinik A, Arezzo J, Bril V, Feldman E, Freeman R, Malik R, Maser R, Sosenko J, Ziegler D: Diabetic Neuropathies. Diabetes Care 2005, 28:956-962.

4. Gupta A, Humke S: The prevalence and management of onychomycosis in diabetic patients. Eur J Dermatol 2000, 10:379-384.

5. Karchmer A, Gibbons G: Foot infection in diabetes: evaluation and management. Curr Clin Top Infect Dis 1994, 14:1-22.

6. Ramsey S, Newton K, Blough D, McCulloch D, Sandhu N, Reiber G, Wagner E: Incidence, outcomes, and cost of foot ulcers in patients with diabetes. Diabetes Care 1999, 22:383-387.

7. Smith D, Weinberger M, Katz B: A controlled trial to increase office visits and reduce hospitalization in diabetic patients. J Gen Intern Med 1987, 2:232-238

8. Block P: The diabetic foot ulcer: a complex problem with a simple treatment approach. Mil Med 1981, 146:644-646.
9. Bild D, Shelby J, Sinnock P, Browner W, Braveman P, Showstock J: Lower extremity amputations in people with diabetes: epidemiology and prevention. Diabetes Care 1989, 12:24-29.

10. Armstrong D: Is diabetic foot care efficacious or cost-effective? Ostomy Wound Manage 2001, 47:28-32.

11. Lavery L, Armstrong D, Vela S, Quebedeaux T, Fleischli J: Practical criteria for screening patients at high risk for diabetic foot ulceration. Arch Intern Med 1998, 158:158-162.

12. Singh N, Armstrong D, Lipsky B: Preventing foot ulcers in patients with diabetes. J Am Med Assoc 2005, 293:217-228.

13. Apelqvist J, Larrson J: What is the most effective way to reduce incidence of amputation in the diabetic foot? Diabetes/metabolism research and reviews 2000, 16:s75-s83.

14. Robbins J: Treatment of onychomycosis in the diabetic population. J Diabetes Complications 2003, 17:98-104.

15. Cathcart S, Cantrell W, Elewski B: Onychomycosis and diabetes. J Eur Acad Dermatol Venereol 2009, 23:1119-1122.

16. Boyko E, Ahroni J, Cohen V, Nelson K, Heagerty P: Prediction of diabetic foot ulcer occurrence using commonly available clinical information: the seattle Diabetic Foot Study. Diabetes Care 2006, 29:1202-1207.

17. Gupta A, Konnikov N, MacDonald P, Rich P, Rodger N, Edmonds M, McManus R, Summerbell R: Prevalence and epidemiology of toenail onychomycosis in diabetic subjects: a multicenter study. $\mathrm{Br} J$ Dermatol 1998, 139:665-671

18. Rich P: Onychomycosis and tinea pedis in patients with diabetes. J Am Acad Dermatol 2000, 43:130-138.

19. Armstrong D, Holtz K, Wu S: Can the use of a topical antifungal nail lacquer reduce risk for diabetic foot ulceration? results from a randomised controlled pilot study. Int Wound J 2005, 2:166-170.

20. Cox N, Colver G, Paterson W: Management and morbidity of cellulitis of the leg. J R Soc Med 1998, 91:634-637.

21. Pierce R, Daugird A: Recurrent leg cellulitis: pathogenesis, prevention and treatment. J Am Board Fam Pract 1992, 5:85-87.

22. Brodell J, Brodell R: Recurrent lymphangitic ellulitis syndrome. Contemp Orthop 1992, 25:461-468.

23. Gupta A, Konnikov N, MacDonald P, Rich P, Rodger N, Edmonds M, McManus R, Summerbell R: Prevalence and epidemiology of toenail onychomycosis in diabetic subjects: a multicentre survey. $\mathrm{Br} J$ Dermatol 1998, 139:665-671.

24. Rich P: Special patient populations: onychomycosis in the diabetic patient. J Am Accad Dermatology 1996, 35.

25. Pomposelli J, Baxter J, Babineau T, Pomfret E, Driscoll D, Forse R, Bistrian B: Early postoperative glucose control predicts nosocomial infection rate in diabetic patients. J Parenter Enteral Nutr 1998, 22:77-81.

26. Doyle J, Boyko W, Ryu S, Gause E: Onychomycosis among diabetic patients: prevalence and impact of nonfungal foor infection. Diabetic 2000, 49.

27. Anarella J, Toth C, Debello J: Preventing complications in the diabetic patient with toenail onychomycosis. J Am Podiatr Med Assoc 2001, 91:325-328.

28. Grant R, Devita N, Singer D, Meigs J: Polypharmacy and medication adherence in patients with type 2 diabetes. Diabetes Care 2003, 26:1408-1412.

29. Tan J, Joseph W: Common fungal infections of the feet in patients with diabetes mellitus. Drugs Ageing 2004, 21:101-112.

30. Gupta A, Humke S: The prevalence and management of onychomycosis in diabetic patients. Eur J Dermatol 2000, 10:379-384.

31. Mayser P, Freund V, Budihardja D: Toenail onychomycosis in diabetic patients: issues and management. Am J Clin Dermatol 2009, 10:211-220.

32. Gupta A, Ryder J, Skinner A: Treatment of onychomycosis: pros and cons of antifungal agents. J Cutan med surg 2004, 8:25-30.

33. Olafsson J, Sigurgeirsson B, Baran R: Combination therapy for onychomycosis. Br J Dermatol 2003, 149:15-18.

34. Faegemann J, Baran R: Epidemiology, clinical presentation and diagnosis of onychomycosis. Br J Dermatol 2003, 149:1-4.

35. Thomas J, Jacobson G, Narkowicz C, Peterson G, Burnet H, Sharpe C: Toenail onychomycosis: an important global disease burden. J Clin Pharm Ther 2010, 35:497-519.

36. Council NHMR: National Health Medical Research Council. NHMRC additional levels of evidence and grades for recommendations for developers of guidelines. Canberra; 2009 
37. Trombly $\mathrm{C}, \mathrm{Ma} \mathrm{H}$ : A synthesis of the effects of occupational therapy for persons with stroke, part 1: restoration of roles, tasks, and activities. Am $J$ Occup Ther 2002, 56:250-259.

38. Maher C, Sherrington C, Herbert R, Moseley A, Elkins M: Reliability of the PEDro scale for rating quality of randomized controlled trials. Phys Ther 2003, 83:713-721.

39. Verspeelt J, Marynissen G, Gupta A, De Donker P: Safety of itraconazole in diabetic patients. Dermatol 1999, 198:382-384.

40. Bohannon N, Streja L: Effectiveness of terbinafine therapy for toenail onychomycosis in persons with diabetes (Abstract). Diabetes 2000, 49 : A195.

41. Sumikawa M, Egawa T, Honda I, Yamamoto Y, Sumikawa Y, Kubota M: Effects of foot care intervention including nail drilling combined with topical antifungal application in diabetic patients with onychomycosis. $J$ Dermatol 2007, 34:456-464.

42. Seebacher C, Nietsch K, Ulbricht H: A multicenter, open-label study of the efficacy and safety of ciclopirox nail lacquer solution $8 \%$ for the treatment of onychomychosis in patients with diabetes. Cutis 2001, 68:17-22.

43. Zheng Y, Wu Y, Chen H, Zhu Z, Liu L, Zeng J: Analysis of the factors influencing the therapeutic effects of onychomycosis. J Tongji Med Univ 2001, 21:259-262.

44. Data on file. East Hanover, NJ: Novartis Pharmaceuticals Corporation. 2000.

45. Rich P, Karchmer A, Atillasoy E: The efficacy and safety of terbinafine in diabetic patients: a multicenter trial in toenail onychomycosis. 58th Annual Meeting of the American Academy of Dermatology; San Francisco 2000.

46. Sadighha A: Onychomycosis: report on experience with itraconazole in 37 patients aged older than 50 years: a multivariate regression. Clin Exp Dermatol 2009, 34:924-925.

47. Gupta A, Gover M, Lynde C: Pulse itraconazole vs. continuous terbinafine for the treatment of dermatophyte toenail onychomycosis in patients with diabetes mellitus. J Eur Acad Dermatol Venereol 2006, 20:1188-1193.

48. Brenner M, Harkless L, Mendicino R, Page J: Ciclopirox $8 \%$ nail lacquer topical solution for the treatment of onychomycosis in patients with diabetes: a multicenter, open-label study. J Am Podiatr Med Assoc 2007, 97:195-202.

49. Pollak R, Billstein S: Safety of oral Terbinafine for toenail onychomycosis. Am Podiatr Med Assoc 1997, 87:565-570.

50. Albreski D, Gross E: The safety of Itraconazole in the diabetic population. J Am Podiatr Med Assoc 1999, 89:339-345.

51. Farkas B, Paul C, Dobozy A, Hunyadi J, Horvath : Terbinafine (Lamisil) treatment of toenail onychomycosis in patients with insulin-dependent and non-insulin dependent diabetes mellitus: a multicenter trial. $\mathrm{Br} J$ Dermatol 2002, 146:254-260.

52. Venkatakrishnan $\mathrm{K}$, Von Moltke $\mathrm{L}$, Greenblatt D: Effects of the antifungal agents on oxidative drug metabolism: clinical relevance. Clin Pharmacokinet 2000, 38:111-180.

53. Tabor C, Parlette E: Cutaneous manifestations of diabetes: signs of poor glycemic control or new-onset disease. Postgrad Med 2006, 119:38-44.

54. Health Care Financing Administration: Health Care Provider News. 1998, 39.

\section{doi:10.1186/1757-1146-4-26}

Cite this article as: Matricciani et al: Safety and efficacy of tinea pedis and onychomycosis treatment in people with diabetes: a systematic review. Journal of Foot and Ankle Research 2011 4:26.

\section{Submit your next manuscript to BioMed Central and take full advantage of:}

- Convenient online submission

- Thorough peer review

- No space constraints or color figure charges

- Immediate publication on acceptance

- Inclusion in PubMed, CAS, Scopus and Google Scholar

- Research which is freely available for redistribution

Submit your manuscript at www.biomedcentral.com/submit
Biomed Central 